\title{
Post-modern Tendency: The Uncertainty in The Rainbow
}

\author{
Xinyu Yang \\ School of Foreign Studies \\ Huzhou University \\ Huzhou, China
}

\begin{abstract}
Research on D.H. Lawrence's works has mainly been focusing on his depiction of sexual love so far, but few turns to his post-modern tendency-uncertain and ambiguous attitudes to sex, if not none. With regard to this point, the paper is to propose this in one of his representative works, The Rainbow. The uncertainty and ambiguity are discussed in three major parts for the three pairs. Lawrence's pursuit of ideal harmony and balance between two genders, while female superiority and male superiority appear alternatively, which discloses his uncertainty conspicuously. What's more, Lawrence's phallus advocate and his feminism form a paradoxical contradiction, showing properly his uncertainty in The Rainbow.
\end{abstract}

Keywords—post-modern; uncertainty; ambiguity; paradox

\section{INTRODUCTION}

D.H.Lawrence, a novelist, essayist, poet and painter, was one of the most versatile, gifted but controversial figures in British history. His insight into nature, Industrial Revolution, Victorian morality and sex is so sensitive and penetrating that it has caused great attention and left incomparable influence on both readers and world literature.

The Rainbow, one of D.H.Lawrence's masterpieces, has inevitably intrigued a large amount of attention. Except for the common analysis of the novel, critics also try to find its implied meaning. All the previous comments are roughly classified into three main aspects: the relationship between men and women and their self-realization; the realistic elements of The Rainbow and the significance of life. Among them, the relationship between men and women overweighs the other two, for it has always been Lawrence's main concern. Researchers have explored quite a lot on how the main characters find their mates both in body and soul, such as Jin Mei's Looking for Fulfillment in the Conflicts and Zhen Xueyan's The Rainbow of Life-An analysis on how to keep a harmonious relationship between man and woman in The Rainbow. They indicate that men and women realize their self-improvement through sexual affairs and the elements that keep their harmonious relationship are also analyzed.

With regard to the realistic elements, denial of Industrial Revolution is always the core. Most scholars point out that in D.H.Lawrence's opinion, Industrialization results in alienation and distortion of human nature. The more industrialized the society is, the more incomplete people become and the harder the search of harmony is. The representative reviews are Unique Lawrence, Unique Rainbow published by Zhang Zhongzai and A Sincere Voice-On the Realistic Characteristics of The Rainbow by Lin Bianshui. Besides denial of Industrial Revolution, the uses of images and symbolic description have also been discussed a lot.

As for the study of the significance of life, Feng Jiqing has stated that "The Rainbow is not a simple story about men and women. It in fact indicates a relationship between individuals and the whole. Lawrence here calls for a new relationship between human beings and waits for the birth of a great people and an ideal society." (Feng Jiqing, 1995:119)

It is clear that the previous study of The Rainbow mainly concentrates on the sexual relationship, women dominance or the image of the rainbow, though the search of harmony and balance is D.H.Lawrence's lifelong pursuit. Lawrence has a conspicuous ambiguity and uncertainty when illustrating the relationship between male and female, which as indicated by the strong conflicts and contrasts, a postmodern tendency.

This paper is to show the conflicts and contrasts in The Rainbow---the revelation of Lawrence's uncertainty.

Like D.H.Lawrence's other works, The Rainbow mainly focuses on the relationship between men and women. However, it is more than that. Lawrence probes deeply into a series of personal relationships in the novel and leaves an open ending. He never hides his intention to the arrival of harmony and balance between different sexes, while he himself betrays his planned thoughts occasionally.

\section{D.H.LAWRENCE'S VIEW ON SEX}

The relationship of human beings, especially the relationship between men and women is Lawrence's major concern, but his opinion changes with time going, like what Simpson said "Lawrence's shifting attitude to the relationship between the sexes is graphically illustrated by the changes that occur in his theories about sex."(Simpson $81)$. 
At the very beginning, he declared "Of course there should be a great balance between the sexes". (Ibid., 94) "In woman man finds his root and establishment. In man woman finds her exfoliation and florescence." (Ibid., 88) Throughout his whole life and writing time, he is in search of the balance of this kind between the sexes. Paul in Sons and Lovers is always on his way to the ideal harmony with the other gender. From his own mother Mrs. Morel to handsome Miriam Leivers and Clara Dawex he meets in his following life, he is asking for someone satisfying him both physically and mentally. It is such perfect co-existence between two genders that Lawrence never stops seeking in his early writing.

However, as time moves on, Lawrence starts shifting his favor between the sexes. Men and women superiority appear alternately in his works, while seeking balance becomes vague.

Sheila Macleod once quoted in her book that 'no wonder [Lawrence] worshipped the phallus...' (Quoted in Macleod 66), and she also mentioned "For the frail and sickly Lawrence, penile erection was a triumphant demonstration of male strength". (Ibid.,) Lawrence himself expresses clearly in his letter to Katherine Mansfield on November $21^{\text {st }}, 1918$, "that women should obey men. And men need to take such advantages and head before women rather than turn back asking for suggestions." (Lawrence 379) "It is the first direct expression of a belief in male superiority..." (Simpson 93) Obviously, Lawrence begins turning his favor to men. To him at that moment, what men need to do is be themselves and they are surely to it well. "He is now concerned to establish a sexual hierarchy in place of his former emphasis on balance and relatedness. One sex is to be given priority over the other." (Ibid.,) Up till then, Lawrence holds his belief in his 'phallic marriage'. His male superiority dominates his major theories and works, swinging from balance to a sexual hierarchy.

Sheila Macleod then remarks that "It seems to me that Lawrence writes more convincingly-more convincingly and more powerfully-about the world of women than he writes about the world of men. The extraordinary thing about Lawrence's fiction (in this context) is not that he writes well about women, but that he writes so badly and ineptly about men." (Macleod 34) His feminism attitudes started shining in his books, i.e. he turned his favor to women rather his former belief.

In most of Lawrence's works from about 1914 to 1920 , he swings between two genders. The Rainbow and Women in Love are both of that type. Though he still tries to gain balance in his writing, his imbalance appears occasionally.

Then, in his later fiction, Lawrence turns back to his male superiority again. The Plumed Serpent "is the first full-length exploration of the theme". (Simpson 134) Immediately after this one, Lady Chatterley's Lover, "a nice and tender phallic novel" (ibid.) to Lawrence, comes into being. That Lawrence shifts his favor again and again indicates his uncertain and ambiguous attitudes towards the ideal harmony, towards the relationship between women and men. Lawrence's uncertain state in his pursuit for mutual and absolute harmony and balance reveals his uncertainty thoroughly.

The so-called uncertainty here refers to the concept which is essential to the philosophical trend Post-Modernism. Baudrillard, J., a famous and significant philosopher in PostModernism, has pointed out that the uncertainly has various connotations in different aspects. "It in the first place refers to the quality that cannot be foreseen. Then, it suggests things that cannot be fulfilled out of question; therefore, they may cause suspicions. Thirdly, uncertainty means things that cannot be foreseen. And finally, it shows the uncertain states that one has made". (Gao Xuanyang 19)

\section{IDEAL HARMONY AND FACTUAL IMBALANCE}

"Of course there should be a great balance between the sexes." (Simpson 94) We can find easily from the quotation that Lawrence declares clearly his intention to his searching for the ideal state between the sexes, i.e. 'a great balance'. However, The Rainbow actually leads to a stronger and more obvious conflict between men and women. D.H.Lawrence's seeking for harmony and balance in fact lapses into disappointment. The final state is thus far from ideal.

\section{A. Shorter Happiness and Stronger Conflicts}

"For Lawrence, the source of all life was in the "the great male and female duality and unity'." (Ibid., 84) We can draw from the sentence that marriage to him is neither submission nor dominance. It is in fact a state in which men and women belong to each other while they still maintain their own, individual selfness. It is also a state where men and women find his or her real self and help fulfill self-achievement. Thus, the 'duality and unity' is reached. However, throughout the three generations, the happiness lasts for a shorter period while the conflict gets stronger and appears more frequently.

The first generation, Tom Brangwen and Lydia Lensky, lives a comparably happy life at the Marsh in spite of the utter foreignness between them. At first, "They were strangers". And Tom even felt that "Such intimacy of embrace, and such utter foreignness of contact" was "unbearable". (The Rainbow 39) Tom's proposal on a stormy and windy night to us readers is impulsive and ridiculous at the very beginning, while they two do try to understand each other after marriage. As to Tom, Lydia fits his desire towards the outside world and with regard to Lydia, Tom makes her realize her self-fulfillment, which is totally different from her first failed marriage. Lydia's words, "Yes, some man will love you, child, because it's your nature. And I hope it will be somebody who will love you for what you are, and not for what he wants of you" (218), to Ursula in the later chapter can also prove that Tom has brought her new understanding about love and marriage. She then realizes her real self and remains her independence for which Tom shows his respect to a certain extent in their marriage.

In this level, we can draw a conclusion that the marital life between Tom and Lydia is the most successful and happy Lawrence presents in this novel. "It is based on Lydia's material and Tom's spiritual needs." (Spear 40) 
Then comes the second generation: Will Brangwen and Anna Lensky, the step daughter of Tom. They leave each a deep and fine impression at the first meeting in Tom's. Anna is interested in Will for his good manner and strangeness which she hasn't got. Meanwhile, Anna's directness and openness also intrigue Will's attention. They get married quickly after they get familiar with each other though their parents show disapproval first. Then "the two took their honeymoon in full hands, alone in their cottage together" (119), indulging themselves totally in sexual affairs. However, the seemingly harmonious sexual affair cannot guarantee the real happiness in their lives. After a short while, the fight between them becomes cruel. Anna realizes that "Church had an irresistible attraction for him" (Will) (131). They are unknown to each other. Therefore, Anna starts to seek shelter from the terrifying life that is, giving birth to babies continuously. While Will turns back to his sculpture, his church and his ambiguous belief. Their marriage develops into Anna's seeming victory but not the balance and harmony Lawrence has been in search of.

The third generation, Ursula and Anton Skrebensky, lives an even more complicated and imbalanced life than the former two generations. There appear more quarrels and separations between these two young passionate fellows. Ursula loves Anton first for his robust body and the irresistibly sexual attraction. She then gets more chances to know the outside world because of the progressing society. The better she is equipped, the more doubtful she becomes, towards both her first love and the old civilization. Her doubts question Anton to silence and indeterminacy. Therefore, the two finally break up. Compared with the former generations, the third one enjoys less happiness and peace but more doubts. They get less satisfaction from sexual affairs for Ursula sees more into spiritual differences. She refuses Anton's proposal and looks for something more than sex though "She suffers repeated frustration in her quest". (Zhang Bochun 229)

\section{B. Capable Women VS Uncertain Men}

"Whilst the Brangwen men toil to preserve the continuity and blood-intimacy of the family, the women look outward to the world beyond Marsh Farm, aspiring towards the spiritual fulfillment and natural superiority..." (Spear 37) Thus, women are getting more and more independent and capable, while men are becoming more uncertain about marriage and life in the novel.

As time goes on, the women in the novel become more capable due to various reasons, such as social ones and selfimprovement. They know better of themselves and the life they want to live. Take Ursula for example, "She became aware of herself,..., that she must go somewhere, she must become something." (The Rainbow 237) She strives hard for her first job and she thinks over her relationship with Anton again and again rather than marry him impulsively, which is the exact case of her mother. She disobeys her father's proposal that she should not go out and work in public; she doesn't want to followsuit what others have arranged for her own life, which, to her, should be up to herself. She sends her necklace to the newly-born baby she and Anton meet near a wharf, for she knows the necklace is hers and she indeed is in charge of it by herself.

Then let's move on to the men. Tom Brangwen lives a comparably harmonious life with Lydia Lensky, though there still lie some disputes. Will just takes submission to Anna and they finally compromise in Anna's victory. While Anton, he even doesn't know why he does this or that. Most of the time, he is questioned to silence by Ursula mainly because of his indeterminacy. That he cannot satisfy Ursula both physically and spiritually results in their final separation. "Even whilst he was with her, this death of himself came over him, when he walked about like a body from which all individual life is gone. In this state he neither heard nor saw nor felt, only the mechanism of his life continued." (The Rainbow 390) Men become more and more out of control of their lives. They fail to meet the women's needs and live more mechanically gradually.

The contrast between the sexes in the development of the story shows us clearly that D.H.Lawrence is uncertain about the relationship between two genders though he always seeks a balanced state between them. The main concern of him is towards wholeness, but there appears more separation and isolation between men and women. He did try, but he failed, maybe unconsciously.

\section{Final Imbalance}

It is because of Lawrence's uncertain attitudes towards men and women that the novel finally ends in an unbalanced state.

Lawrence is in search of harmony and balance, while the novel actually ends in a state far from his desire. Lawrence shakes between women and men because he himself is not sure how they can reach the ideal state and what is in fact the ideal. Thus, in the novel, we readers sometimes see male superiority but sometimes male inferiority. The second generation can show the point best.

Anna marries Will in great passion. What they care is not how to make a living but the need in mutual and mysterious attraction due to different genders. However, satisfaction in sexual affairs is not the equivalence to happiness. Soon after their wedding ceremony, they become "enemies". They both want to control the other one and they both want to be dominant but submissive. On the one hand, to Anna, "always, her husband was to her the unknown..." and "this frightened her." (The Rainbow 141) However, she does not make efforts to know her husband better through mutual communication or other effective means. What she does is "preserve herself" and seek her own shelter. On the other hand, Will also does not give in. He returns to his own world, a world of churches and sculpture, a world holding his own belief that is totally incomprehensible to Anna. "They were ashenly miserable for some time. Then the life began to come back." (The Rainbow 143) They are drawn into a situation in which their marital life is full of unsteadiness and susceptibility. Therefore, peace and quietness appear hardly in their marital life. 
"And ever and ever again he appeared to her as the dread flame of power... She waited upon him and heard his will, and she tremble in his service."

"Then all this passed away. Then he loved her for her childishness and her strangeness to him, for the wonder of her soul ... And she loved him for the way he sat loosely in a chair, or for the way he came through a door with his face open and eager." (The Rainbow 142)

All those show Lawrence's uncertainty towards the relationship between the sexes. Women and men have their own fields in which they show their superiority and power. Thus the novel ends in imbalance rather than harmony Lawrence desires for. The factual imbalance and Lawrence's original pursuit have formed a "paradoxical contradiction", which is a facet of uncertainty.

\section{Phallus AdVocate VS StRong FEMINISM}

Lawrence himself claims to be a phallic marriage advocate, while in the novel we can sometimes see clearly his feminism. The contradiction also indicates his uncertainty.

As what is mentioned in the very beginning, Lawrence "worshipped phallus". He never hides the fact that he is member of "phallic marriage". While we can notice his feminism in The Rainbow easily, no matter how this comes into being.

\section{A. Tom's Rejection and Anna's Insistence}

Tom Brangwen's first objection towards Anna's marriage is meaningless to Anna. She just sticks to her own decision.

Anna's decision to marry Will seems unacceptable to her father. To him, "She was a child, a mere child" and "She did not understand what she was doing" (98), so Tom shows his disapproval for Anna's sake. Upon Tom's disagreement, Anna reacted hysterically. She just cried out to Tom that "You are not my father-my father is dead-you are not my father", (The Rainbow 105) which is an unbearable torment to Tom. He knows to certain extent, "He is isolated from her. There was a generation between them... He felt the inevitable coldness... He sat in his coldness of age and isolation." (The Rainbow 105-106) In order to show her determination and get an absolute say over her own affairs, "Anna kept out of sight as much as possible." (The Rainbow 105) As to Anna, nobody can say no to the things she's already decided. Her self-centeredness starts when she was just a little child. Finally, Tom gives his way. "..., he handed over the shares he had transferred to Anna Lensky", (ibid.,) though he suffers a lot in his deep heart from the decision.

Anna shows exactly women power is stronger and tougher than that of men. Such feminism betrays Lawrence's declaration of being "phallus worshipper". Thus, "In Lawrence's usage, 'phallic' loses its association of thrusting aggressiveness and takes on feminine connotations..." (Simpson 134)

\section{B. Anna's Naked Dance and Will's Final Compromise}

Anna's dancing without clothes shows clearly her independence and strength. Will finally makes compromise to her.

"Motherhood gives women too much power. This I believe to be Lawrence's basic attitude..." (Macleod 153) During her pregnancy, Anna shows her power to a greater extent than ever. Will does try to make her realize that "manhood is more important than childhood...", but he fails. (ibid.,)

Anna and Will's marriage is in fact a bitter and miserable struggle for dominance. Neither of them is willing to give way or show respect for the other's independence, therefore, quarrels are frequently aroused between them, ending in sexual affairs, which consoles them both momentarily. Conflict reaches its peak when Anna is pregnant. Once she realizes "for her there was no final release", (The Rainbow 152) she feels a sudden impulse to dance nakedly, of herself and for herself. "She danced in secret before the Creator, she took off her clothes and danced in the pride of her bigness." "... She danced exulting before her Lord, and knew no man" (The Rainbow 153), including her husband Will. Her naked dance is a revolt to Will's "imposing his will on her". She dances as an absolute individual in her real self, which is out of Will's expectation. Such crazy behavior "hurt him [Will] as he watched as if he were at the stake... The strangeness, the power of her in her dancing consumed him, he was burned, he could not grasp, he could not understand". (Ibid.,) To mother Anna, she doesn't want Will to "interfere with her" and she can do "as she likes". Motherhood, "it harms men, in excluding and downgrading them, and is indeed intended to destroy their manliness". Anna triumphant shows exactly this point. (Macleod 153)

In the end, Anna becomes "Anna Victrix". "He [Will] could not combat her any more. He was out in the wilderness, alone with her." (The Rainbow 161)Will thus makes compromises to her because of his declining manliness.

\section{Ursula's Independence VS Anton's Incapability}

Ursula's independent thinking finally makes her go over her relationship with Anton and decides to break up.

As an educated and modern young lady, Ursula appears more rationale than her ancestors. She thinks and acts independently, though she also endures sufferings from her new thoughts. However, she makes it finally, i.e. to keep her pursuit rather than yield to the undesirable reality.

We cannot deny that Anton does bring Ursula satisfaction in sex and fulfill her curiosity. "Ursula is full of love and eager towards Anton when he is seen as a single young man" (Feng Jiqing 114) rather than a tiny unit of the ruling class which Ursula resents to utmost. However, after Ursula goes over her relationship with Anton, her sense comes above her sensibility. Therefore, she finally decides to break up with him. It is not because Anton has got married. The root lies in, "Anton is far far away from what Ursula is looking for. He hasn't got his true self, which means that he lacks the uniqueness Ursula possesses". (Ibid., 112) She is 
"against" Anton, and all his "old, dead things". (The Rainbow 390) And she even remarks to Anton that "You seem like nothing to me". (The Rainbow 261)

Yes, she suffers quite a lot from her failed first love. Yet, the main miseries are due to "the disappointment brought by the conflicts and fights inside her heart". (Feng Jiqing 112) Fortunately, Ursula herself realizes it in time and "stands up again from the decline and feels her new way in the current endless darkness". (Ibid., 113) Their final separation is inevitable.

Men are not that determined and capable as they were. They either make compromises or escape from the things or people that make them confused and uncertain. Women, by contrast, are surer about what they are longing for and what decisions they should make upon themselves. Lawrence reverses his former belief between female and male, which indicates his vague and uncertain attitudes.

\section{LAWRENCE'S AgNOSTIC ATtiTUdES}

Lawrence's uncertainty in The Rainbow can also be illustrated from his agnostic attitudes. In The Rainbow, 'unknown' is a frequently appeared word. The "unknown" between women and men and the "unknown" towards the progressing society are both Lawrence's concerns. He is uncertain for he feels himself out of control. He has his original pursuit, but he betrays it as the story goes on. His agnostic attitudes finally results in the separation between the main characters.

\section{A. Anna's Fear of Divorce}

Though strong-willed, Anna only tries to find shelter from giving birth to babies continuously where "she finally finds her self-confidence and power over Will" rather than gets divorced for she is unsure about the future. (Spear 41)

We can see easily from the novel that Anna Lensky is strong-willed and tough. Even when she is little, she shows a great sense of possession. She is aware of what she owes and she knows how to make it her advantages.

When Lydia Lensky and Tom Brangwen decide to get married, Anna shows her disagreement at the very beginning for she does not want "her" mother to go. Her mother should be hers, totally. She doesn't like to share her belongings with others. Though they two marry, "she [Anna] was a sore problem to Brangwen and to all the people at the Marsh". (The Rainbow 55) "I don't like you to do that, mother" or "I don't like you to say that" (Ibid.) are her shibboleth in daily life.

Anna indeed gains plenty of attention and love when she lives at the Marsh, from both Tom and others around. She may take it for granted that her life would go on in this way. However, we've talked above that her marital life with Will is not that harmonious and happy as she has expected. Will shows great interest in churches, but "he paid no more attention to that part of the service which was Church to her". (The Rainbow 131) That cannot be understood by Anna, and "angered her more than ever". (ibid.,)
Though she sometimes is in dominance and Will does be subsevient to her, she still cannot satisfy. What she needs is absolute power and dominance over others but not occasional and unsteady rule. She cannot stand the fact that "He was not interested in the thought of himself or of her: oh, and how that irritated her!'(Ibid.,)

As Anna fails to communicate with Will both physically and mentally, she turns herself to continual labor where she finds great senses of achievements and victories. With the child coming, "Anna lapsed into vague content". (The Rainbow 164) However, she dares not declare divorce for she is uncertain of the life she may be involved in. Whenever she is frustrated by Will, "an ashy desolation came over her". (143) "There was something beyond her. But why must she start on the journey?" "Why should she travel further?" (The Rainbow 163) Thus, she gives up her pursuit and "becomes complete gradually". (Feng Jiqing 108) "With satisfaction she relinquished the adventure to the unknown." (The Rainbow 164)

\section{B. Ursula's Momentary Homosexual Experience}

Ursula's transient and failed homosexual relationship with her teacher, Miss Inger, shows Lawrence's attempt on the way to the harmonious but agnostic world.

The arrival of harmonious world in which women and men live in a balanced state is Lawrence's lifelong pursuit. A world that has got "new architecture" and in which "the old, brittle corruption of houses and factories swept away, the world built up in a living fabric of Truth, fitting to the overarching heaven". (The Rainbow 418) In seek of such balance; Lawrence has made plenty of attempts. His dealing with the relationship between women and men can best test his attempts, either showing his feminism or male superiority on the way to his balance.

The conventional thought about marital happiness lies in the combination of one woman and one man. Yet, after his two unsatisfying couples, Lawrence turns to a new pattern of arriving at his ideal, i.e. combination between two young passionate women.

Winifred Inger, a school mistress of Ursula, develops an intimate term with Ursula. They two even have physical attraction toward each other. Facing and touching Inger, "Ursula's heart was beating so fast" and "she was beside herself". (284-285) they two soon start sharing a same friend circle, exchanging their beliefs and reviews on social movements and other activities. However, all those only last for a short period. Then Ursula starts to reject Inger who she has admired and obeyed at the beginning. "Sometimes she [Ursula] thought Winifred was ugly, clayey."(The Rainbow 289) And "she wanted some fine intensity, intensity, instead of this heavy cleaving of moist clay, which cleaves because it has no life of its own". (ibid.,) Their affair "begins in idealistic physic adoration while passes away in spiritual shame". (Spear 44)

Such lesbian relationship is one of D.H.Lawrence's attempts to harmony and happiness. However, it finally fails in shame. Lawrence cannot help trying in this way for he 
himself is uncertain how he will reach his ideal in such an agnostic and chaotic world. Such uncertainty is due to the things that cannot be foreseen by Lawrence, a single human being.

\section{Lawrence's Ambiguity through Anton}

Anton can't even tell why he fights for the so-called civilized society, for Lawrence shows his ambiguity.

Anton is no more than a member of the old community which stands on the old civilization, composed of decline and darkness, to which Ursula, a fair modern young lady with independent and rational thoughts, shows her contempt and disgust. Anton, "he is engaged in his obligations; he devotes himself totally to the task on hand and endures great sufferings", but he cannot tell exactly why he needs to do it. (Feng Jiqing 113) He just feels that he has to and he should. He wants to go to India to fight for his motherland, as he claimed, while, to Ursula, it is all nonsense. He is just "seduced beast in sheep's clothing and primeval darkness falsified to a social mechanism". (The Rainbow 378) His real, individual self has already gone and "his life now is based upon the established order". (Feng Jiqing 113) Ursula, on the other hand, explains in great rage why he wants to join in the war. She knows that Anton doesn't mainly fight for his country. In fact, he fights for his own profits.

Ursula's inquires make Anton lapse into silence and uncertainty. He can't persuade Ursula for Lawrence himself is ambiguous.

Freud has once mentioned that the creation by writers or poets is in fact a course of daydream. Daydream is a privilege to those whose hopes are not fulfilled in the real society. Therefore, the characters created by writers reflect to some extent the writers' own illusion or hopes. Thus, Anton, a main character in The Rainbow, reveals Lawrence's inner thoughts. Lawrence shows strong disapproval of Industrial Revolution and the so-called civilization, which indicates he is not satisfied yet he can do little. Therefore, Lawrence pours his dissatisfaction and ideal into his characters. Anton's bewilderment and confusion are in fact due to Lawrence's ambiguity, from which the uncertainty of him is betrayed. According to Ihab Hassan, an American philosopher and critics, "ambiguity is a composition of uncertainty". (Tong Li 311) Thus, Lawrence shows his uncertainty through his vague views illustrated by Anton's ignorance.

\section{CONCLUSION}

Uncertainty, the essence of Post-Modernism, is shown clearly by Lawrence in his novel The Rainbow, though he himself may be unaware of it.

As a genius in the literary world, Lawrence has gained great attention, compliment as well as blame. He is now an established and universally acknowledged novelist for his special and audacious works. His brave and direct descriptions of sexual affairs which he names to be the source of life and should be emancipated also cause an enormous amount of controversy. The Rainbow, one of his masterpieces, thus is inevitably paid much attention to.

Many people have stated that The Rainbow depicts vividly the relationship between two genders. Lawrence tells a story of three generations. Each generation shows a type of relationship between couples, more exactly, women and men. They either remain comparatively happy and satisfied with each other or break up with the other one and pursuit the life they themselves want to live. Except for the self-fulfillment and the pursuit for harmony and balance between women and men indicated by those critics, Lawrence also shows his uncertainty in dealing with the women-men affairs. That is a conclusion we can jump to on careful and rational analysis, i.e. Lawrence also suggests his uncertain attitudes while searching his ideal state.

The first generation lives in comparable happiness compared with the latter two generations. That does not mean that there are no disputes between them. They are still unknown to each other because of different backgrounds. They can remain happy for they are harmonious in sexual affairs and they do not make detailed inquiries as to what leads to their discrepancy and how it comes into being. They can stay in comparable happiness for they easily ignore their unknown parts to each other. They stop entering the outside world and satisfy with the simple happiness they are now preserving.

The second generation is turbulent to a certain extent. Though they can get a sense of ecstatic satisfaction in making love, they cannot communicate with each other spiritually. Their final pursuits differ from each other's. Anna dances nakedly to show her disagreement and rebellion with Will while Will turns back to his own churches when he fails to get satisfaction from Anna. They two even have the impulse to kill each other when they are in heavy quarrels. Such turbulence obviously violates D.H.Lawrence's pursuit of harmony. That contradiction between his planned thoughts and his factual frustration reveals his uncertainty in his search

The disputes between women and men go to their peak in the third generation who break up before joining in wedlock. Their division lies basically in their different beliefs and dreams. They can't understand and agree with each other's outlook in various circles. Their separation seems unavoidable from the very beginning. That is totally different from Lawrence's plan. Ursula's homosexual relationship with her teacher is a brave attempt for Lawrence to reach the harmony, but it lasts only for a while and finally fails. That's the uncertainty Lawrence shows in his pursuit. He tries to rearrange the relationship between one sexes to arrive at the balance of the whole mankind as he has longed for.

The apparent narration and the writer's factual pursuit have formed a paradoxical contradiction, which shows properly the uncertainty of Post-Modernism. Such uncertainty makes it possible that every single utterance has no fixed standard. That the latter sentence overturns the former one and the latter behavior denies the former one is the direct result caused by such uncertainty. Then, an indescribable self-removal state is thus formed. 
Besides, Lawrence's claim of being a phallus worshipper and the development of the novel itself in which strong feminism can sometimes be seen also show Lawrence's uncertain attitudes towards the relationship between women and men. The women of the novel become more and more educated, independent and certain about themselves and their life, while men step back in the opposite way. All those can suggest Lawrence's uncertainty.

All in all, Lawrence's uncertain attitudes towards life and sexual relation can be found through a scrutiny into his works. It is safe to run to the conclusion that Lawrence's uncertainty is surely displayed in his book, The Rainbow.

\section{REFERENCES}

[1] Lawrence, David Herbert: The Rainbow. Hertfordshire: Wordsworth Editions Limited, 1995.

[2] Macleod, Sheila: Lawrence's Men and Women. London: William Heinemann Ltd, 1985.

[3] Spear, Hilda: The Edition of York Notes: The Rainbow. Beijing: Longman York Press, 1989.

[4] Simpson, Hilary: D.H.Lawrence and Feminism. Beckenham: Croom Helm Ltd, 1982.

[5] Jiqing, Feng, A Commentary Biography of D.H.Lawrence, Shanghai:Shanghai Literature and Art Publishing Group, 1995. 冯季 庆, 《劳伦斯评传》, 上海: 上海文艺出版社, 1995。

[6] Xuanyang, Gao, Postmodernism, Beijing: China Renmin University Press, 2005. 高宣扬, 《后现代论》, 北京: 中国人民大学出版 社, 2005。

[7] Junfeng, Dong \& Chunhua, Zhao, "A Review of D.H.Lawrence Research in China”, Foreign Literature Studies, 1999/2: 115-118. 董 俊峰, 赵春华, “国内劳伦斯研究述评”, 《外国文学研究》, 1999/2: 115-118。

[8] The Collected Letters of D.H.Lawrence, ed, Harry. T. Moore, London: Heinemann, 1962. 哈里 - 莫尔编, 《劳伦斯书信选》, 刘宪之, 乔长森译, 哈尔滨: 北方文艺出版社, 1988。

[9] Hongling, Hao, Individuality and Harmony: Women's Holy Grail, [Master Degree Thesis], Jilin University, 2006. 郝红玲, “个性与 和谐: 女人的圣杯--劳伦斯三部小说的女性主义解读” , 吉林大 学, 优秀硕博论文, 2006。

[10] Li, Tong, Research on the Philosophical Trends of Western Postmodernism, Tianjin: Tianjin People's Publishing House, 2003. 佟 立, 《西方后现代主义哲学思潮研究》, 天津: 天津人民出版 社, 2003。

[11] Freud, Sigmund, Eros and Civilization, Hefei: Anhui literature and Art Publishing House, 1987. 西格蒙德・弗洛依德著, 《性爱与文 明》, 合肥: 安徽文艺出版社, 1987

[12] Boxing, Zhang, A Course of British Literature and American Literature, Wuhan: Wuhan University Press, 2001. 张伯香, 《英美 文学教程》, 武汉: 武汉大学出版社, 2001

[13] Hongxia, Zhao, Lawrence's Text World: Interrogation and Reconstruction to the Relationship of Soul and Body, [Master Degree Thesis], Shandong Normal University, 2006. 赵洪霞, “劳伦斯的 文本世界：对灵与肉关系的质问和重构”, 山东师范大学：优秀 硕博论文, 2006。

[14] Weihua, Zhong, "A feminist reading of Rainbow", Journal of Shaoguan University, 2000/5: 69-72. 钟伟华, “《虹》”的女性文学 色彩” 《韶关大学学报》, 2000/5: 69-72 